\title{
CHARTIST DISTURBANCES IN NORTHEASTERN ENGLAND, $1839^{1}$
}

In all of the writing on Chartism, virtually no attention has been paid to the movement in northeastern England. Tucked off as they are in a remote corner of the country, Newcastle, Sunderland, and the industrial and mining communities around have been neglected by scholars who usually mean Lancashire and the West Riding of Yorkshire when they speak of "the North". Yet Chartism in Northumberland and Durham attained a stridency and vehemence which was rarely matched and never excelled elsewhere.

Activity in the area early took on a striking militancy. An extensive organization was built up, spilling over into Scotland and the English counties around the Northeast. Talented leaders were attracted both from the local area and other sections of the country. One of the best Chartist newspapers originated in Newcastle and week after week it urged adoption of the Charter's Six Points of Parliamentary reform. As time went on the more outspoken members of the movement assumed a greater ascendancy and their language took on a more pronounced tone of violence. By February I 839 Newcastle was one of three areas in the country attracting especial attention from the Home Office because of suspicion that arms were being collected there. ${ }^{2}$ In the spring outdoor meetings drew increasingly large numbers to hear emotional exhortations by local and national leaders who threatened vague but menacing measures which would be taken if Chartist demands were not granted.

During the summer 1839 determination such as this was tested by Parliament's refusal to consider the National Petition and, more concretely, by measures taken by the public authorities to preserve the peace. As in most places, the magistrates of the Northeast had taken few precautions to deal with disorderly and unlawful action before the tense weeks from June to August. They remained passive while the Chartists grew steadily in strength and more reckless in language. However, in July one incident in county Durham and two in Newcastle alerted the magistrates to the dangers. In conjunction

1 The author wishes to express his gratitude to the Leverhulme Trust, the American Philosophical Society, and the Faculty Research Committee of the University of Oklahoma for their assistance and encouragement in the research upon which this paper is based.

2 Asa Briggs, ed., Chartist Studies, London 1959, p. 377. 
with the military they hastened to take steps which deterred most workers from answering the call for a general strike in August and thus enabled them quickly to cope with the few who did quit work. These events in the Northeast present a striking illustration of how masses of people were swept up in the turbulence of early Chartism and how rapidly Chartist strength dissipated when it encountered determined police resistance.

$$
* * *
$$

The background to the disorders of summer 1839 begins about a year before. John Collins, a delegate from the Birmingham Political Union, visited the district in early June 1838 and after hearing Collins' description of the objectives and political methods of the Chartists, meetings in Newcastle on June $2^{1}$ and Sunderland on June $4^{2}$ passed resolutions approving the Charter and the National Petition. Later, on Queen Victoria's coronation day, June 28, a mass meeting of men from the Tyne and the Wear gathered on the Newcastle Town Moor to hear speeches favoring reform and to endorse the Petition. ${ }^{3}$

During the following autumn Newcastle and Sunderland both formed associations to promote the Charter. Newcastle revived the Northern Political Union of I83 I-32, while Sunderland established the Sunderland Charter Association, later to become the Durham County Charter Association. ${ }^{4}$ The two associations remained distinct, each retaining its own leadership and carrying on separate activity, largely through sending missionaries out into the countryside and by holding public meetings in town. Generally speaking, the Northern Political Union operated on both banks of the Tyne and throughout Northumberland, while the Sunderland group worked among the colliers and town workers in county Durham as far south as the Tees. There was some overlap in their work in north Durham, but this did not appear to produce strain between the two groups. On the contrary, there was frequent cooperation between them in holding mass meetings and exchanging speakers, and ordinarily they acted as two parts of the same movement. Meanwhile, Newcastle's excellent "Northern Liberator", along with the "Northern Star" and Chartist newspapers from other regions, helped focus grievances and provided links with fellow complainers elsewhere.

1 Newcastle Courant, June 8, 1838 .

2 Northern Liberator, June 9, 1838 .

3 Ibid., June 30,1838 .

4 Formed in Newcastle on September 10. See Northern Liberator, September 15, 29, I838. Formed in Sunderland on November 21. See Northern Liberator, November 24, I 838 ; Sunderland Beacon, November 28, 1838 . 
The new movement came to fertile ground - fertility, however, not because of great hunger and economic hardship among the working population. On the contrary, the district for some time had enjoyed great growth and prosperity to the benefit of almost all groups of workers.

The discontent sprang from other sources. The Northeast in the second quarter of the nineteenth century was in a stage of rapid economic growth and was experiencing sharp dislocation as a result of this expansion. Coal mining had been important for centuries, but new demand for steam, coking, and gas coal and technological changes in mining led to the sinking of many new pits and the revival of old ones in the late $1820^{\prime}$ 's and $1830^{\prime}$ s. $^{1}$ Railways, which were first developed in this area to carry coal from the mines to the sea, had made mining possible in areas hitherto inaccessible and had opened the way for large scale railway construction. ${ }^{2}$ Addition or improvement of port facilities along the Durham and Northumberland coasts greatly increased the capacity of shipping facilities to handle the new coal tonnage. The shipping and shipbuilding industries also experienced a corresponding boom; Sunderland, the principal shipbuilding center in the area, saw an increase from 98 vessels built in 1835 to 247 in 1839 , representing more than a doubling in tonnage launched in a year. ${ }^{3}$ Industries which used coal, or which serviced it and the shipping industries, also prospered. A glass industry, since disappeared, flourished on both the Tyne and the Wear. Pottery, chemicals, brickmaking, rope and sail-making, paper-making from rope scraps, all were expanding industries. And this prosperity was reflected in new construction in the area, most notably in the Grainger-Dobson reconstruction of the central district of Newcastle, just being completed in 1839 .

Industrial growth had brought a very substantial population increase to the coal field and industrial towns, both through movement townward from the rural areas of the counties and by immigration into the region. The mining population had always been mobile, moving from place to place as work expanded or declined, but the changes of the second quarter of the nineteenth century have been described as revolutionary. ${ }^{4}$ New recruits came from a number of places - lead

\footnotetext{
${ }^{1}$ Arthur E. Smailes, The Development of the Northumberland and Durham Coalfield, in: The Scottish Geographical Magazine, LI (1935), pp. 205-207.

2 Matthias Dunn, An Historical, Geological, and Descriptive View of the Coal Trade of the North of England, Newcastle upon Tyne 1844, pp. 54-55.

${ }^{3}$ Taylor Potts, Sunderland: a History of the Town, Port, Trade, and Commerce, Sunderland 1892 , pP. I02-I03.

4 Arthur E. Smailes, Population Changes in the Colliery Districts of Northumberland and Durham, in: Geographical Journal, XCI (Jan.-June I938), p. 223.
} 
miners from exhausted workings in Cumberland and elsewhere, colliers from Scotland, Wales, and the Midlands, Irish and Scottish peasants who first migrated into the area as seasonal agricultural workers, blackleg labor brought in during past strikes. Wherever they came from, they introduced a new and unassimilated element into a population that had lived with a settled culture, accepted patterns of work, and traditions connected with the occupation of mining. ${ }^{1}$ Likewise the growth of the towns attracted outside elements. In Newcastle, for instance, the Grainger-Dobson building project in the town center had swelled the building trades with newcomers, particularly stonemasons, and the city's unusually high crime rate was attributed to the restlessness of this group. ${ }^{2}$ In this atmosphere of movement and unsettled social conditions, strongly felt grievances arose and strove for expression.

With the aid of a long Radical tradition, dating at least from Peterloo, these discontents focused on a political outlet. Chartism became grafted onto earlier demands for reform, such as requests for expanded franchise and the protest against the Poor Law Amendment Act already under way in the region.

As the movement spread it drew support from numerous sources. Some participants were middle class Radicals, motivated by reasons of principle, for whom Chartism provided yet another hope of winning universal suffrage. Others were small shopkeepers, newsagents, booksellers, or public house keepers, whose occupations gave them frequent opportunity for conversation and exchange of discontents. As the movement progressed, a number of Chartist leaders abandoned their usual occupations to become newsdealers or publicans and certain shops or pubs became regular meeting places. The immigration of labor from other parts of England or from Scotland and Ireland brought unsettled people, many of whom were recruited to Chartism. In Newcastle a special effort to win over the Hibernian Society was finally successful in July I $8390^{3}$ The Northeast also attracted agitators from other parts of the country by the vehemence of its support for reform. Feargus O'Connor, John Taylor, Thomas Ainge Devyr,

\footnotetext{
${ }^{1}$ E. Welbourne, The Miners' Unions of Northumberland and Durham, Cambridge 1923, p. 46.

2 John Stephens, Abstract of a Return of Prisoners coming under the Cognizance of the Police of Newcastle upon Tyne during the ten months from the 2nd of October 1837 to the 2 nd of August 1838 , in: Journal of the Statistical Society, I (1839), pp. 324-26. Comment on Newcastle's unusually high crime rate in this paper read before the British Association meeting in Newcastle in 1838 suggests this factor.

3 Northern Liberator, July 20, 1839.
} 
George Julian Harney, and other outsiders are important throughout the movement.

Certain groups of workers stand out as supporters. The shoemakers of Newcastle and Gateshead, "... being deeply convinced that we never can fully protect our labor with our unions, and believing that the establishment of universal suffrage is the only means of securing a full protection and remuneration of our labor", took a prominent role. ${ }^{1}$ Others from the shipbuilding and chemical industries frequently turn up in reports of meetings. In Newcastle the building trades were important, possibly because of concern over the ending of the central district reconstruction, but probably because of bad relations between the men and their employers which continued throughout the period.

More important than any of these, however, were the iron workers across the river from Newcastle in Winlaton and the coal miners of both counties. The iron workers were part of the "factory" of small craftsmen established by Ambrose Crowley in I690, which has received frequent attention from economic historians. The industry was then in decline as more favorably placed or more progressive iron works developed elsewhere in the country, and the workers were among the few in the region hard pressed at this time. A strong sense of pride and local identity had grown up in the past in the ironmaking villages, and, faced with a reverse in their trade, the workmen stood together in the forefront of Tyneside Chartism. ${ }^{2}$

The backbone of the movement were the coal miners. The mining population had been restless for years. The agitation for the first Reform Bill had taught them the value and technique of organization and had led them into two great strikes in $183 \mathrm{I}$ and 1832 . The coal field remained restless during the rest of the $1830^{\circ} \mathrm{s}$ with complaints about wages and terms of work at binding time, changes in the method of measuring the coal mined, hazards of working, child labor, and the like. ${ }^{3}$ Other factors contributed as well. The areas of recent expansion and a large influx of outsiders saw most trade union and Chartist activity. ${ }^{4}$ These regions were in some cases more dangerous to work, and there is some reason to believe that the hazard and uncertainty of working conditions contributed to the contentiousness

1 Ibid., March 2, 1839 .

${ }^{2}$ Newcastle Weekly Chronicle, June I4, I 873.

${ }^{3}$ In 1836 a large meeting of the pitmen of the Tyne and the Wear addressed a series of resolutions to the coal owners asking them to redress these grievances and hinting at legislative remedy or strike action if nothing was done. Newcastle Chronicle, September 24,1836 .

4 Welbourne, p. 47 . 
of the miners. Finally, mention must be made of the influence of Primitive Methodism among the mining community. Local preachers or the "Ranters", as they were called, filled with unmistakable frequency the multiple roles of religious leaders, pit workers, trade union officials, and Chartists. From the Primitives were borrowed the model of class organization, the enthusiastic open air meeting, the technique of hortatory speaking, and a fervent conviction of the worth of the individual. ${ }^{1}$

The Chartists became increasingly truculent in the early summer of 1839 as time for the presentation of the National Petition grew near. At great Whit Monday meetings held "simultaneously" with others throughout the country in support of the Petition, speakers discussed the application of "ulterior measures" in case of its failure. It was on this day that a Newcastle mason and prominent Chartist, James Ayre, said he was tired of "the manner in which he had been agitating and he next meant to agitate the bricks and mortar." On the same day in Sunderland the Durham county delegate to the National Convention, Robert Knox, argued, "... the majority has a right to use any means that will gain [its] rights. If fighting in the field with the pike or musket will get those rights, the people have the right to use the pike and the musket."3

During June Chartist statements became even more alarming. Early in the month the shopkeepers of the anomalous parish of Bedlington near Newcastle were terrorized by the violent tone of two Chartist meetings led by Henry Cronin, a recently arrived stonemason's laborer. Later Cronin led a large body of unruly men, many of whom were alleged to be in debt to the tradesmen, on a "canvass" to determine which dealers were for and which against them. Repeated appeals from local people for protection finally led to the stationing of two Metropolitan police officers in the parish and the swearing of two special constables. ${ }^{4}$ At the time of the presentation of the

I Ibid., pp. 54-59; Sidney Webb, The Story of the Durham Miners, 1662-1921, London 192 I, PP. 21-24; Thomas Burt, Methodism and the Northern Miners, in: Primitive Methodist Quarterly Review, new ser., IV (July I 882), pp. 390-93.

2 Newcastle Courant, May 24, I 839.

3 Sunderland Herald, May 24, 1839.

4 Series of correspondence between residents of Bedlington, Lord Howick, and the Home Office, June, I 839, Public Record Office, Home Office Papers, 40/42 (Home Office Papers hereafter cited as "H.O."). Bedlington was one of the several detached portions of county Durham which lay entirely within Northumberland and were not united with the northern county until $\mathrm{i} 844$. Residents complained repeatedly of the inadequacy of police protection and the difficulty of getting Durham magistrates to hold petty sessions to punish offenders. 
Petition to the House of Commons, the Northern Liberator warned against the use of arms at the moment, but said "that is no argument against HAVING THEM IN CASE OF NEED." It went on to ask whether the Petition would have received such a courteous reception by the House, "had the one million, two hundred and eighty thousand men who sent this Petition ... NOT had pikes, muskets, and pistols at home?"1 A week later, commenting on a Lord's debate on the disturbed condition of the country, the Liberator said, "It is the CHARTER that has assisted to do this; but above all it is THE ARMS - THE ARMS THE ARMS! Let, then, Lord Melbourne, let lord Brougham, and above all let Strathfieldsaye, let the 'Hero of Waterloo' 'deprecate' away; but for every 'deprecation,' let the people ... 'arm' more and more, until they are weaponed to the very teeth."'2

In this atmosphere of heightening tension any frustration of the Chartists was likely to provoke disorder. Nearly a week before word of the rejection of the Petition reached the Northeast, three incidents occurred which implied government suppression of Chartism. These were the Birmingham riots of July 4; the arrest of one of Newcastle's delegates to the National Convention, John Taylor, in Birmingham; and the arrest of another, George Julian Harney, at Bedlington on Monday, July 8 . Word of the Birmingham disturbances reached Newcastle on Saturday, July 6, and was followed on Sunday morning by news that Taylor had been arrested for sedition. The apprehension early Monday morning of Harney at Bedlington was known almost immediately in Newcastle, but Sunderland did not hear of any of the events before Tuesday morning, July 9. The Chartists of both towns responded immediately and kept the district in a disturbed state until late August.

The first incident of disorder occurred in county Durham on July 9. After learning of the riots and arrests, the Durham County Chartist Association posted bills calling a meeting on the Sunderland Town Moor for the same evening and dispatched couriers to the colliery villages to summon the miners of the county. The meeting took place with James Williams, an unusually intelligent young bookseller and one of the two key Chartist leaders in Sunderland, presiding. It proceeded as planned but in its midst a long train of railway wagons drew up alongside the Moor and discharged a load of men from the colliery districts. According to Williams "there was 1000 at least."3

1 Northern Liberator, June 22, 1839.

2 Ibid., June 29, 1839.

${ }^{3}$ From a letter written the same night by Williams to Newcastle, Northern Liberator, July 13,1839 . 
The men came from Thornley, Haswell, and South Hetton, all collieries in the recently developed and more unsettled east Durham coal field. Earlier in the day the news brought by two emissaries from Sunderland had aroused the men at Thornley not actually working. They in turn had gathered the surface workers and tried to have the men underground brought up. The colliery agent arrived in the midst of this uproar and tried to calm the men down. However, they rejected his persuasion and, armed with staves, toured the village, forcing hesitant colleagues to join them. They then set off for the Sunderland meeting, stopping at Haswell and South Hetton to collect more followers. On the way they forcibly took possession of wagons and trains on the Durham and Sunderland Railway and compelled the engine drivers to run them into the town, arriving with sensational effect. ${ }^{1}$ The meeting resumed without further incident and when it broke up some of the miners who had come on trains found their way back the same way, while others were given emergency accommodation in Sunderland and Monkwearmouth.

Although no injury or destruction of property occurred during these proceedings, they caused considerable alarm. Men had abandoned work, others had been compelled to join the demonstrators against their will, and property had been forcibly seized for their purposes. The magistrates quickly took action. The Durham magistrates went immediately to Thornley and swore in over one hundred special constables, as well as calling for troops from Newcastle. ${ }^{2}$ In Sunderland three of the pitmen who attempted to force the railway to carry them away from the town on Tuesday night were fined five pounds each and were committed to Durham goal for three months when they could not pay. ${ }^{3}$ More important, under the pressure of alarmed townspeople, the Sunderland magistrates took action against James Williams and his partner in Chartism and bookselling, George Binns. They did so diffidently, but with moral and financial support from the Home Office, on July 22 they charged the pair with using seditious language in their speeches of July 9 and in a handbill issued later in the week entitled "An Address to the Middle Classes."4

1 Sunderland Herald, July I 3, I 839; Northern Liberator, July 13, 1839; Clerks to Sunderland magistrates to Lord John Russell, July 13, 18, 1839 , Durham magistrates to Russell, July I5, I839, H. O. 40/42.

${ }^{2}$ Durham magistrates to Russell, July I5, I839, H. O. 40/42.

${ }^{3}$ Newcastle Journal, July 13, I839.

4 Clerks to Sunderland magistrates to Russell, July I3, I8, I839, H. O. 40/42; J. M. Phillipps to Clerks, H. O. 41/14, ff. 19I-92; Phillipps to Sunderland Mayor, ibid., ff. 239-40. An identical address was issued in Newcastle and is discussed below. The arrests are described in the Sunderland Herald, July 26, 1839, and the Newcastle Journal, July 27, I 839. Binns and Williams were later sentenced to six months imprisonment. 
Elaborate police precautions against demonstration were taken prior to the arrest. All of the special constables then sworn, about 170 , were called out and a placard was distributed in the town warning against illegal meetings and calling for the enrollment of more special constables. The commander of the troops in the local barracks was alerted and a loan of spare arms from the Coast Guard commander was secured. The special constables remained on duty every night during the next week, with justices in constant attendance in case of disorder. ${ }^{1}$ The sole effort at protest, however, was a hastily summoned meeting on the Town Moor on the night of the arrest, and it dispersed quietly when the magistrates pointed out the prohibition of meetings to the chairman. The actions of the magistrates successfully quieted Chartist activity in Sunderland, for, although effort was made to organize the various trades into Chartist groups of their own and occasional indoor meetings were held, no more open meetings with their potentiality for riot took place till after the attempted general strike in August.

If Sunderland Chartism was tamed before the end of July, the case elsewhere was much different. When news of the Birmingham riots and Taylor's arrest reached Newcastle on Sunday, July 7, the local Chartists called a protest meeting at which the language was so violent that it led subsequently to the indictment of five of the speakers. One of them, Bronterre O'Brien, on his first visit to Newcastle, urged, "If the people's blood was shed in the peaceful discharge of their right of meeting, why, let the borough magistrates be answerable in life and property." Another, John Mason, a local shoemaker, accused the Birmingham authorities of "high treason against the queen and constitution", and said, "he would rather see every village in the country a smoking ruin - he would see the black demon of desolation spread its wings over the land, rather than see the present system of oppression continued much longer."2

Harney's arrest the following day aroused even greater feeling. He was taken at one o'clock Monday morning ${ }^{3}$ by a Birmingham and two Metropolitan police officers on a charge of having used seditious language at Birmingham on May I4. They brought him to Newcastle and put him on a train for Carlisle a few hours later. ${ }^{4}$

1 Sunderland Herald, July 26, I839; Sir Hedworth Williamson to Russell, July 22, 1839, Clerks to Sunderland magistrates to Russell, July 29, I839, H. O. 40/42.

2 Northern Liberator, July I3, I839.

3 The Chartists later eagerly dramatized this fact, alleging that he had been "torn from the arms of his wife in bed." Harney was unmarried at the time. (A. R. Schoyen, The Chartist Challenge, London 1958, p. 74; Newcastle Weekly Chronicle, March 8, 1873.) Letter from Harney, Northern Liberator, July 13, 1839. 
Newcastle learned of the arrest from printed placards which summoned a meeting for Monday evening in an open recreation ground called the Forth near the center of the town. Many workmen, including those unemployed as a result of a joiners' strike and some of Grainger's masons who had downed tools on hearing of Harney's arrest, gathered in small, agitated groups throughout the day to discuss the news. Some were reported to have paraded weapons openly. ${ }^{1}$ Late in the afternoon bands and marchers, many of them armed, arrived from Winlaton and Swalwell, where Harney enjoyed great popularity. ${ }^{2}$ They remained in the working-class district of the Side near the river until about eight, when they marched in procession to the Forth for the meeting. Thomas Hepburn, the miners' leader who had restrained the pitmen from violence during the great strikes of $183 \mathrm{I}$ and 1832 , called for orderly conduct, but the speeches that followed included references to "blood for blood" and more warnings to the magistrates for their responsibility "both in person and property, for any injury that may be sustained by the people."3 After resolutions condemning the arrests, many demonstrators paraded through the town once more, this time stopping to "utter groans" before the house of the superintendent of police. Although no injury occurred, the town was kept in an uproar past midnight.

This was the first of a series of meetings held nightly in the Forth for over a week. Each afternoon similar groups collected near the Side to await the arrival of the Winlaton ironworkers with their band and banners. After remaining there for some time while the band played, the crowd moved off in procession, sometimes passing through Gateshead first, and then by a circuitous route through central Newcastle to the Forth. Because of the eagerness for information from other places, the meetings consisted chiefly of readings from newspaper reports from other sections of the country or letters from Chartist figures known locally and in listening to travelers' descriptions of regions from which they had just come. ${ }^{4}$ Upon conclusion, the procession was reformed and, after another march through the town, dispersed quietly. Except for the display of two pikeheads the first night and the allegation of the discharge of two pistols in the procession

1 Northern Liberator, July I 3, I 839; Northern Star, July I3, 1839.

2 Schoyen, p. 47.

${ }^{3}$ Northern Liberator, July I3, I 839.

4 James Williams' description of the Sunderland meeting was read at one of these meetings, while letters also came from Taylor, Harney, and the third Convention delegate from Newcastle, Robert Lowery. In the absence of reliable information extravagant rumors circulated including claims of a Chartist uprising in Carlisle and the refusal of the military to fight against the people in Glasgow. (Northern Liberator, July I3, I839.) 
away from the Forth on the second, the meetings remained orderly and were unmolested by the police. ${ }^{1}$ One journal went so far as to say that they were "rather recreative to many and [more] amusing to the inhabitants than otherwise" and reported that children had taken to "playing" at being Chartist as a new diversion."

In spite of their good behavior, the Chartists grew steadily less playful in their mood and language. On Wednesday night, July io, the public meeting called upon the Convention to designate a day for the beginning of a general strike and the same views were expressed strongly by delegates from several areas at a Northern Political Union Council meeting which followed. ${ }^{3}$ The Council's decision to coordinate northeastern strike action with the rest of the country deflated excitement somewhat, but not enough to discourage another meeting in a heavy rain on Thursday or to prevent two collieries from stopping work in anticipation of the strike. Discussion of the "Sacred Month" continued for the rest of the week and on Sunday afternoon, July I4, 40,000 men of the Tyne were pledged "ready to vindicate their liberties," to be supported on a few hours' notice by 20,000 more from the Wear. All were urged to organize in groups of tens, fifties, and hundreds in preparation for its commencement. ${ }^{4}$

Meanwhile on Thursday the Council of the Northern Political Union had issued "An Address to the Middle Classes of the North of England", appealing "in the Language of Brotherhood probably for the last Time" for their support against "a perfumed, insolent, idle Aristocracy." It called for their assistance in accomplishing "a change which it is not your Power to avert, though it is in your Power to give it a peaceful character", and it promised "Vengeance, swift and terrible" would overtake them if they "assisted the Aristocracy to murder" the working classes. ${ }^{5}$ These did not seem empty threats, for it was well known that the Chartists were in possession of weapons such as daggers, pikeheads, "craa's feet" or caltrops for injuring horses' hooves, and a few firearms, all but the latter capable of being made by the metal workers at Winlaton and Swalwell. The fiery shoemaker, John Mason, had claimed on July 9, that 10,000 pikes had been ordered, although by whom and from where was unclear. ${ }^{6}$

${ }^{1}$ Newcastle Journal, July 13, 1839; Gateshead Observer, July 30, 1839.

2 Newcastle Courant, July I9, I 839.

3 Northern Liberator, July I3, 1839 .

4 Ibid., July 20, 1839.

5 Enclosure with Duke of Northumberland to Russell, July 20, 1839, H. O. 40/46. Mark Hovell in The Chartist Movement, Manchester I925, believed this address probably to be the work of Bronterre O'Brien (p. 169). This is the same handbill which figured in the charges against Williams and Binns in Sunderland.

6 John Latimer, Local Records, Newcastle 1857, III, p. I 3 . 
The rejection of the National Petition by the House of Commons, news of which reached the Northeast on Sunday evening, July $\mathrm{x}_{4}$, severely disappointed the local Chartists and hardened their determination. Discussion of arming became more outspoken at the meetings and various "ulterior measures" such as withdrawal of savings bank deposits, teetotalism, and securing goods on credit were strongly recommended. The suggestions seem to have had considerable effect for in both counties small shopkeepers surmised from the increase in purchases and the decrease in cash payments that the pitmen were stocking up for the strike, while calls on savings banks shortly became very heavy. ${ }^{1}$ The Newcastle Chartists wanted the strike to begin in a week on July 22 and pressed this date on the National Convention, in spite of a letter from Robert Lowery advising August I 2 because of the inconvenience it would cause to harvesting and the time needed to inform the country of the issues. ${ }^{2}$ By Wednesday, July 17, the Council of the Northern Political Union concluded that the nightly meetings in Newcastle had served their purpose, and issued a notice that in the future only a weekly meeting would be held on Tuesday. Instead trade and district organizations were urged to improve their organization for the strike which was expected shortly. ${ }^{3}$

The tenor of the Chartist meetings and the unquestioned possession of arms by many of their participants alarmed many of the residents of the town, particularly after word of a second series of disturbances in Birmingham arrived on July i 8 . The magistrates, however, remained complacent and decided to permit the meetings so long as "no direct breach of the peace was committed." Newcastle had reorganized its police in 1836 , and the magistrates relied on the regular force of the town, reinforced if necessary by troops from the local garrison, to keep order. Newcastle's mayor, John Fife, while not a Chartist himself, had been a member of the Northern Political Union during the earlier Reform Bill agitation and favored further extension of the franchise on a gradual basis. Throughout the summer he counseled moderation in dealing with the Chartists and on July ig reported to the Home Office, "At the present moment we are not apprehensive of any outbreak."4

\footnotetext{
${ }_{1}^{1}$ Newcastle Journal, July 27, 1839; Charles William Bigge to Lord Howick, August 8, I 839, Papers of the Third Earl Grey, Prior's Kitchen, Durham Cathedral (hereafter cited as "Grey Papers").

2 Newcastle Courant, July 19, 1839 .

3 Ibid.

4 Fife to Russell, July 19, 1839, H. O. 40/46.
} 
Hardly had he sent off his report when a disturbance occurred which revealed the troubled state of the town and the inadequacy of its police forces. On Saturday night, July 20, a street brawl started outside a public house at the foot of the Side. When a policeman interfered and arrested one man, the crowd forced his release. Meanwhile a second fight broke out at the head of the Side which the police were unable to break up without reinforcements. As they retired, a considerable crowd collected and moved off in the direction of the central district of the town, breaking gas lamps on the way and throwing stones and bricks at buildings. They did especially serious damage to a bank on the square of St. Nicholas' Church and made a concerted attack on the windows of the Tyne Mercury, a newspaper critical of Chartism. Police reinforcements arrived to scatter the crowd as they returned to the Side, but it was three a.m. before the streets were quieted.

Several men were arrested in the course of the disturbance and testimony at the assizes trial which followed shortly indicated its origin as nothing more than a drunken street fight. It appeared to grow out of hand because of the inadequacy of police forces, an interpretation which testimony from police constables aged I I, I6, 59, 67, and 70 bears out. ${ }^{1}$ Some of the town's newspapers alleged that Chartist leaders joined the mob and tried to direct it against the Chartists' own enemies, pointing to the attack on the Tyne Mercury and the breaking of gas lamps as in Birmingham as evidence. ${ }^{2}$ What seems more likely is that the disorderly crowd, gathered in a working class area of Chartist sentiment, seized on the first likely targets. Because of Chartist excitement, the Tyne Mercury office aroused particularly destructive zeal, but the windowbreaking was probably spontaneous rather than premeditated or managed.

The mayor took a moderate view of the riot but the experience clearly pointed out the weaknesses of the police force and startled him and other authorities out of their complacency. At an unusually well-attended meeting the following Monday, the borough Watch Committee recommended that the strength of the police in the town be doubled for the duration of the emergency, raising the force to nearly two hundred. ${ }^{3}$ In addition the Watch Committee authorized the police superintendent to provide an additional station nearer the

\footnotetext{
1 Newcastle Courant, July 26, 1839.

2 Newcastle Journal, July 27, I839; Tyne Mercury, July 23, 1839.

${ }^{3}$ Borough of Newcastle upon Tyne, Watch Committee Minute Book, July 22, 1839, I, pp. I I - I 1 6. Later, on reconsideration, this recommendation was reduced to so men, but this augmentation was maintained until late autumn (Watch Committee Minute Book, July $3 \mathrm{I}$, 1839, I, p. I 17 ; Town Council Reports [1 839], p. 6; Newcastle Journal, December I4, I 839).
} 
center of the town than the main station and to deposit arms there under proper security. It also suggested to the magistrates that they enrol special constables and prohibit meetings in the borough "at late or improper hours."

The first of the weekly Tuesday night Chartist meetings on July 23 spurred the authorities to further action. Statements such as that of one speaker who denied Chartist complicity in the "child's play" of window-breaking of the preceding Saturday on the grounds that the Chartists "would not think of touching their enemies until they could break both their windows and their heads together", started the magistrates collecting evidence to establish a charge of sedition. At the same time they requested, unsuccessfully, that additional cavalry be stationed in the town to deal with disturbances in the nearby collieries and also arms for 1000 special constables whom they expected to be sworn. ${ }^{1}$ The day after the Forth meeting they also published a handbill forbidding any further public meetings.

The ban on public meetings forced the Chartists to consider whether to defy the magistrates by holding their weekly meeting in the Forth the next Tuesday, July 30. On Saturday the council of the Northern Political Union, meeting in private, decided to evade the prohibition by requisitioning the mayor to call a meeting. On Monday they submitted such a request, ostensibly to address the queen in opposition to the increase in the standing army and the adoption of a rural police bill then under consideration in Parliament. While the Chartists awaited an answer, their tempers were frayed further by the indictment for sedition of five of the speakers at the meeting held on July 7 . The reply from the mayor and magistrates, refusing the requisition as inconsistent with their earlier proclamation, came at six in the afternoon of Tuesday, July 30 , too late to prevent the arrival of the men of Winlaton with their band. The Chartist leaders decided to go ahead with the usual procession and meeting in spite of the refusal. This meeting, peaceful enough for most of its duration, ended in a clash with the police which was later to be called the "Battle of the Forth".

The main body of the Chartist procession went to the meeting ground, but many people remained milling about the streets in an angry mood. The mayor and other officials of the town attempted to persuade them to disperse, but were greeted only with jeering. The mayor then sent word for the police, special constables, and military forces to assemble while he and his party went on to the meeting area. There they met people coming from the meeting as it finished and were jeered and pelted with stones. The mayor called his various forces

${ }^{1}$ Newcastle Courant, July 26, I839; Fife to Russell, July 24, 1839, H. O. $40 / 46$. 
into action and a struggle ensued. During the course of the disorder the Riot Act was read several times, and Lt. Col. Colin Campbell, commander of the Newcastle garrison, threatened to fire on some groups if they did not disperse. Through the combined use of cavalry, infantry, and the civilian police forces, the streets in the vicinity of the Forth were cleared by midnight and a number of prisoners taken. ${ }^{1}$

Old Chartists harbored the bitterest of feelings about this incident for decades. R. G. Gammage alleged that the mayor led a "physical force party" in an attack calculated "to strike a blow at the right of public meeting."' In 1873 an unsigned account asserted:

"The Battle of the Forth was the Peterloo of Newcastle, happily differing from the Manchester event in its stopping short of legalized crowd slaughter, but otherwise characterized by the same daring assertion of human rights and the same harsh measures of repression on the part of those in authority". ${ }^{3}$

Even George Julian Harney, who wrote over fifty years later and acknowledged the restless condition of the town, believed, "The authorities were or professed to be alarmed and steps were ... taken which were only too likely, even if not calculated, to provoke a conflict, and which steps led directly to what has been too grandiloquently termed 'the Battle of the Forth'." 4 They repeatedly claimed that the procession away from the Forth was attacked without sufficient provocation and that excessive force was used in dispersing the crowds, while they turned their scorn on Mayor John Fife for the apparent inconsistency between his actions in 1839 and his ultraRadical words as a member of the Northern Political Union in $1832 .{ }^{5}$

These accusations do not seem to be justified. The mayor and his colleagues made strenuous efforts to quiet the crowds in spite of their unruly mood. Instead the mayor was abused and, according to many Chartist, as well as official, reports, assaulted with stones and brickbats. From all but the most directly interested accounts it appears that the

1 Town Council Reports (1839), pp. I5-18; Newcastle Weekly Chronicle, March 8, I873; Harney account, ibid., July 19, 1890 ; Letter from a participant in the procession, ibid., August 9, 189o. The Northern Liberator, August 3, 1839, denied that any objects were thrown, while R. G. Gammage in his History of the Chartist Movement, and ed., Newcastle 1894 , claimed "but few were made use of" in spite of their accessibility (p. 149).

2 Gammage, p. 149.

3 Newcastle Weekly Chronicle, March 8, 1873 .

4 Ibid., July I9, I89o.

5 The Chartists were even further embittered by the award of a knighthood to Fife the following year "as a mark of approbation of the manner in which he sustained the office of chief magistrate under very critical circumstances." 
provocation came not from the police, but from the Chartists and that the mayor, having exhausted all other means at his disposal, had little other choice than to order his forces to quell an excited and riotous crowd. It is surprising that so few casualties occurred in the engagement that followed rather than the town having been given over to "whatever outrages a band of unprincipled mercenaries were pleased to inflict on them."1

$$
* * *
$$

From the end of July attention fixed on the general strike. The National Convention had earlier proposed August 12 as the day of its commencement, but on receiving reports from delegates from various parts of the country, it equivocated and postponed the strike until an indefinite time in the future. ${ }^{2}$ This anti-climax left local Chartist organizations without the guidance of national leadership and they lost what unity of purpose had existed previously. The Northeast reflected the confusion in the rest of the country in the way some groups determined to go ahead, while others hung back until they saw what chances there were for a successful outcome to the strike.

Despite the shock of the July 30 collision with authority, the Newcastle Chartist leadership held to the plan for an August I 2 work stoppage. At an indoor meeting on Tuesday, August 6, speakers, several of whom were later arrested for their remarks, called for the general strike. At the weekly Council meeting of the Northern Political Union on Wednesday reports were read from over forty of the surrounding communities favoring the strike and it was resolved with one dissenting vote to begin the "Sacred Month" on the following Monday. ${ }^{3} \mathrm{~A}$ handbill announcing the strike as "the only peaceable way in which the Power of the People can be made felt by the bad Men who oppress them", was issued on Thursday. ${ }^{4}$

The announcement, however, did not arouse much support among the workers of the town. Although "a gloomy \& vindictive feeling" had prevailed among "the deluded portion of the working classes" after the chastening rebuff of the Forth, the cessation was expected by the mayor to be only partial. ${ }^{5}$ The local press revived the confident and condescending tone that it had used toward the Chartists before

\footnotetext{
1 Northern Liberator, August 3, 1839.

2 Hovell, pp. 167-7o.

${ }^{3}$ Gateshead Observer, August Io, 1839 . Perhaps the Newcastle movement was influenced in its decision by the presence of Robert Marsden, one of the most ardent advocates of the strike, at the previous night's meeting.

${ }^{4}$ Enclosure in Fife to Russell, August IO, I 839, H. O. 40/46.

${ }^{5}$ Fife to Russell, August 4, IO, 1839, H. O. $40 / 46$.
} 
the movement became too alarming and warned the misguided followers against unscrupulous leaders who "should have been put in the pillory and pelted with rotten eggs."1

Conditions elsewhere varied considerably. At Sunderland the combined effect of generally good working conditions and the earlier measures taken by the magistrates made the Chartists reluctant to follow their Tyneside brethren until they had tested the willingness of other groups in the area to strike. Unlike the earlier "Address to the Middle Classes", the Durham County Charter Association issued a conciliatory tract by their Convention delegate, Robert Knox, on "The Duty of the Middle Classes to Support the Chartists", in which he said "Labor and capital are like the two halves of a bank-note - useless when separate, valuable when combined."2 When the Northern Political Union designated August 12 as the day for beginning the strike, James Williams wrote expressing surprise that Newcastle took its decision without consulting other Chartists in Northumberland, Durham, and Cumberland, and, instead of supporting the choice, he invited Newcastle to send representatives to a meeting of trades' and other delegates in Sunderland on the evening of the 12 th. The meeting continued from six in the evening until five the next morning, when, by a narrow majority, it was decided that in spite of "warm admiration for the spirit displayed by the men of the Tyne, ... the general holiday at present is unadvised and premature and ought not now to take place."3 Earlier a meeting at Darlington had decided that the southern portions of the county were not yet sufficiently organized to keep the "Sacred Month".4 At South Shields, where the movement was less strong and where the Political Union had already thrown its support behind the owners of a local alkali works in mutual defense against a farmers' protest about air pollution, four hundred of the workers were sworn in as special constables. ${ }^{5}$

Strongest support for the strike came from the small iron works on the south side of the Tyne and from some of the collieries. Winlaton was expected to stop work and became more restive as the day approached. On the night of August I the village became so disorderly that the following night the magistrates swore in special constables there and prohibited further meetings in the parish. ${ }^{6}$ The iron workers

\footnotetext{
${ }^{1}$ Newcastle Journal, August ro, 1839.

${ }^{2}$ H. O. 40/5 I, f. 134.

3 Northern Liberator, August 10, I839; Durham Advertiser, August I6, I 839; Gateshead

Observer, August 17, 1839; Newcastle Courant, August 16, 1839 .

4 Northern Star, August 3, 1839.

5 Newcastle Courant, August 16, 1839.

${ }^{6}$ North Durham magistrates to Russell, August 3, 1839, H. O. 40/42.
} 
were so fearful of a police attempt to confiscate their supplies of arms that when a false alarm was sounded of the approach of troops from Newcastle, men took up defensive positions on all approaches to the village and the stock of arms was hidden in the country around. ${ }^{1}$ Although most of the collieries were not prepared to support the strike, some in both counties had large numbers of Chartists among the workmen and a halt to work as well as possible violence was expected on August I2. The magistrates of Northumberland consulted with the colliery agents and viewers of both the Tyne and Wear and their consensus was that the most serious spots were Thornley and South Shields in Durham and Heaton, Seghill, Tyne-Main, St. Lawrence, Holywell, West Cramlington, and Cowpen in Northumberland. ${ }^{2}$ The chairman of the Northumberland magistrates was especially worried about Seghill, Cowpen and Cramlington and wrote to the deputy lieutenant: "I never remember this country in so hazardous a state before. Some measure must be taken by $\operatorname{Parl}^{t}$ to conciliate the popular feeling which is so general \& determined or we shall incur the risk of a revolution." ${ }^{3}$ Even in towns where there was little likelihood of violence, the residents feared what might happen if men of the nearby mining areas should turn on them. ${ }^{4}$

The magistrates made what preparations they could before the designated Monday. Newcastle's augmentation of its force of regular police was followed by Gateshead. ${ }^{5}$ In most places the magistrates exercised their authority, upon presentation of information of threat of riot or disorder, to swear in special constables. The Castle Ward, or southern, division of Northumberland pressed fit Chelsea outpensioners into service, as well as the usual volunteers. ${ }^{6}$ The men were armed with cutlasses and pistols supplied by the order of the Home Secretary, but requests for muskets were refused. ${ }^{7}$ An irregular and untrained force, not always made up of men of serious motive, the special constables could not have been the most reliable support to the customary civil forces, and the Northern Liberator wryly contrasted their behavior at the "Battle of the Forth" with the discipline

\footnotetext{
1 Tyne Mercury, August 6, I 839; Durham Advertiser, August 9, 1839 .

2 Enclosure with Duke of Northumberland to Russell, August I3, I839, H. O. 40/46; John Buddle to Marquess of Londonderry, August I I, I839, North of England Institute of Mining and Mechanical Engineers, John Buddle Papers, Letter Books, II, item I3 (Buddle Letter Books, II, hereafter cited as "Buddle").

${ }^{3}$ Bigge to Howick, August 8, 1839 , Grey Papers.

4 Newcastle, Durham City, South Shields, and Morpeth all mentioned this strongly in their letters to the Home Office.

${ }^{5}$ Gateshead magistrates to Russell, July 31, I839, H. O. 40/42.

${ }^{B}$ Northumberland magistrates to Russell, August I, I839, H. O. $40 / 46$.

7 Phillipps to Bigge, H. O. 4I/I4, f. 345 .
} 
of the regular police and military. In at least two places organization of voluntary associations to provide more cohesion and better training was proposed, but the Home Office showed no enthusiasm for this idea and delayed decision on one of the plans until the worst danger was over, when it discouraged it. ${ }^{1}$ One official, Thomas Bowes, bailiff in Darlington, took advantage of the disturbed conditions to advance his own interest. The magistrates of Darlington were surprised to find that he undertook correspondence with the Home Secretary without their knowledge. Their surprise perhaps would have been greater had they been aware that Bowes also had urged that a commission of the peace be joined to his office of bailiff in order better to guarantee the town's safety. ${ }^{2}$

In addition to strengthening police forces, the magistrates sought to forestall violence by preventing gatherings and by giving maximum publicity to the police action that had been taken. Public notices prohibiting meetings were posted in many places while in others local officials refused to give their sanction to requests to call meetings. Gateshead also issued a notice warning persons who had been conducting military training and exercises that they were liable to imprisonment or transportation and called for assistance in their apprehension. ${ }^{3}$ It was also hoped that public announcement of the recruitment of special constables and the appointment of additional police would have a deterrent effect on troublemakers. Some magistrates acted upon their belief that large numbers of the Chartists were unwilling followers of the movement by publicly promising protection to the lawful and warning against intimidation. ${ }^{4}$

Military forces garrisoned in barracks at Newcastle, Tynemouth, and Sunderland stood ready to give assistance to the civil authorities if necessary. Although responsible to General Sir Charles Napier, commander of the Northern District in Nottingham, the crucial decisions on what aid to render, and when, lay with the local garrison commanders. Colonel Campbell had already won the praise of Newcastle for the support and assistance given by his troops on July $30 .{ }^{5}$ Yet the magistrates feared interruption of communications or delay in the arrival of troops in case they were needed and tried to reassure

1 Fife to Russell, August 4, 1839, H. O. 40/46; Phillipps to Fife, H. O. 41/15, ff. 5-7; Stockton magistrates to Russell, August 22, I839, H. O. $40 / 42$.

2 Thomas Bowes to Russell, July 23, August 9, 1839, Darlington magistrates to Russell, August 3, 1839, H. O. 40/42.

3 Gateshead magistrates to Russell, July 31,1839, H. O. $40 / 4^{2}$.

4 Handbill issued by the magistrates of the east and west divisions of Castle Ward, Northumberland, H. O. $4 \% / 46$.

${ }^{5}$ Fife to Russell, August 3, 1839, H. O. $40 / 46$. 
themselves by taking further steps. John Fife of Newcastle asked for a piece of artillery which could be fired from the roof of the town gaol as a signal to the troops in the barracks about half a mile away, but as in the case of the voluntary associations, the Home Office delayed a decision until calmer conditions permitted an indefinite postponement. ${ }^{1}$ More often communities away from the garrison towns requested that detachments of troops be stationed in their precincts to eliminate the time which would elapse in summoning them from their barracks. One leader writer had earlier called for one hundred troops to be placed at every colliery where trouble was anticipated, ${ }^{2}$ but the magistrates of Morpeth, South Shields, Stockton, and Durham wanted detachments of soldiers in their towns to protect them from an influx of colliers from the surrounding area.

Such requests placed heavy demands on the troops available in the area and ran counter to the policies adopted by General Napier for meeting the Chartist disturbances. He discouraged applications for troops because he preferred to concentrate his forces in a few key places rather than scattering his forces "over the country as if shaken out of a pepper box."3 The plea of Morpeth was rejected, presumably because of the accessibility of the Newcastle garrison to the disturbed colliery areas, but the Home Office honored those of Durham, South Shields, and Stockton, the latter over the explicit objection of Napier. ${ }^{4}$

When troops were sent out, Napier insisted that units of two companies of infantry and one of cavalry be kept together and that they be provided adequate barracks in places not vulnerable to attack or encirclement. He disliked the separation of his forces into small groups because of its possible effect on discipline and morale, and he sought to guard against this by keeping men in reasonably large sized groups and in as comfortable accommodations as possible. To avoid the fillip to Chartist morale of a victory as well as to protect the welfare of his men he wanted barracks at the edge of the towns rather than in the center where the troops might be trapped in narrow streets or in buildings which could be set afire.

Provision of barracks was a major obstacle in Durham where the magistrates wished to house the men in the Castle to save money, and it was not until the Home Office provided assistance with the costs that appropriate quarters were found. ${ }^{5}$ Later a similar request

\footnotetext{
${ }^{1}$ Fife to Russell, August 6, 1839, H. O. 40/46; Phillipps to Fife, H. O. 41/14, f. 478.

2 Durham Advertiser, July I9, 1839.

3 Napier to Phillipps, H. O. 4\%/53, ff. 561-64.

4 Ibid.

5 Napier to Phillipps, H. O. 40/53, ff. 573-76; Exchange of correspondence between

Durham magistrates and Home Office in late July and early August, H. O. 40/42.
} 
for assistance with barracks expenses from South Shields was rejected, but the Home Secretary did have a sloop of war stationed in the Tyne to provide protection for shipping and better communication across the river to the garrison at Tynemouth. ${ }^{1}$ Berwick was also allowed to tap local forces if needed, being authorized to call on the Coast Guard. ${ }^{2}$ As an additional reinforcement to the authorities, the Northumberland and Newcastle Yeomanry Cavalry were placed on the alert, although there was no call for their services. ${ }^{3}$

When Monday, August 12, came, the strike call failed dismally in most places. Although the Durham County Charter Association had not yet taken a definite position on the strike, the postponement of decision until after the meeting of trades' delegates in Sunderland on Monday evening averted any action that day in most of county Durham. Similar reluctance to strike kept Darlington and Stockton quiet. In Newcastle no men struck, and placards calling a meeting of strikers in the Forth in the afternoon resulted only in a desultory gathering of about forty, most of whom were idle in any case. ${ }^{4}$ In spite of the anxious demands for troops from Durham City, South Shields, and Morpeth, no incidents occurred in the towns or their environs and military assistance was unnecessary.

What stoppages occurred were in the collieries and Winlaton. All of the south Durham collieries stopped and it was reported that not less than 1,000 men were idle, with the danger that sailors and others dependent on the coal trade would be thrown out of work. ${ }^{5}$ Conditions further north in the county were better, where only the men of Thornley of the Wear collieries struck the first day. They were joined the following day by Littletown and Sherburn, and it was only with difficulty that Pittington and Pensher were persuaded to work. A few men stayed out at Shiney Row, and John Buddle, agent for the Marquis of Londonderry, feared that the whole colliery as well as Pittington would go out the third day of the strike. ${ }^{6}$ The collieries of the Wear, however, appeared to take their lead from the deliberations of the Council of the Charter Association which met with delegates from

${ }^{1}$ Clerks to South Shields magistrates to Russell, August I3, I839, H. O. 40/42; Phillips to Clerks, H. O. $4 \mathrm{I} / \mathrm{r} 4$, ff. $437,473$.

2 Phillipps to Mayor of Berwick, H. O. 41/14, f. 397.

3 Duke of Northumberland to Lt. Col. Bell, August 2, 1839, Alnwick Castle, Duke of Northumberland's Letter Books, November I 2, I 83 I-August I, I 844, ff. 264-65. For permission to consult these papers the author is indebted to His Grace the Duke of Northumberland.

${ }^{4}$ Fife to Russell, August I2, 1839, H. O. 40/46; Newcastle Courant, August 16, 1839.

${ }^{5}$ Stockton magistrates to Russell, August 14, 1839, H. O. 4\%/42.

6 Buddle to Londonderry, Buddle, item 18. 
the region nightly in Sunderland. The Monday night resolution was an expression of the delegates of trades rather than a formal policy of the Association, but on Tuesday, the 13 th, the Council decided against the strike in the colliery districts because it could not be carried without the support of the towns. ${ }^{1}$ This brought the Durham strikes to an end, although colliery agents and magistrates continued to be apprehensive about further outbreaks.

On the Tyne and northeast of Newcastle a number of collieries came out. Colonel Campbell reported only four collieries north of the Tyne struck on the first day, ${ }^{2}$ but John Buddle informed the Marquis of Londonderry that eighteen of the collieries of the Tyne valley and Northumberland were out. ${ }^{3}$ At others, such as Walbottle and Gosforth, portions of the work force struck. There was danger that the strike would spread after the first day and that striking workers would force those still on the job to come out with them. However, the combination of quick action on the part of the magistrates and the restraint of the strikers themselves prevented this and by the end of the week all pits were back in operation.

The most serious spot was Seghill and the surrounding area. Chartist feeling there was stronger than anywhere else in the Northumberland colliery districts, and the Chartists began their strike by firing guns at three o'clock in the morning, which were answered from nearby Cramlington. A meeting of the men of Cramlington, Seghill, West Cramlington, Holywell, Hotspur, and Cowpen was planned for ten in the morning at Whitridge to decide what action the men should take toward other collieries. ${ }^{4}$ The magistrates in Newcastle, learning of the meeting and with the support of a force of cavalry and infantry under the command of Colonel Campbell, went out "to take such measures as circumstances required, to disperse any tumultuous or seditious meeting that might be held, and to hold out protection to the well-disposed."5 The men were already dispersing quietly when they arrived and they told the magistrates that they had resolved not to interfere with anyone who wished to continue work. Only the Seghill men refused to talk to the magistrates - "They were sulky and would not talk any" - and the men there remained out of

\footnotetext{
1 Buddle to Mills, Buddle, item 19.

2 Campbell to Phillipps, August I3, r839, H. O. 40/46.

${ }^{3}$ Buddle to Londonderry, Buddle, item i4. He listed Benwell, Fawdon, Heworth, Hotspur, Pelaw-Main, Springwell, Tanfield Lea, Usworth, Cowpen, Cramlington, West Cramlington, Holywell, Low Moor, Sheriff Hill, Stormont, Garesfield, Netherton, and West Towneley. He omits Seghill which also struck.

4 Ibid.

5 Sir M. W. Ridley to Duke of Northumberland, August 15, 1839, H. O. 40/46.
} 
work the following day. ${ }^{1}$ In spite of the peaceableness of the meeting, however, the magistrates toured a considerable portion of the district to reassure the "well-disposed". Troops from Tynemouth were stationed in Earsdon on Monday night and moved to Seghill on Tuesday as a further guarantee. Years later Thomas Burt, Secretary of the Northumberland Miners' Association and M.P. for Morpeth, recalled childhood memories of cavalry trotting past his door near Seghill. ${ }^{2}$ The arrest and sentencing of a number of Chartist leaders at Seghill for breaking their bonds ended any resistance, and the collieries of this area were back to work on Thursday.

Near Bedlington, a bit further north, more serious activity threatened temporarily but also was averted. At Cowpen colliery the men had decided at a seven a.m. meeting to strike and to give other collieries notice to follow them. They barricaded a square in the village against police interference and were only prevented from moving two small guns from the quay into the square by the breakdown of their wheelbarrow. Failing this, they armed themselves with pikes and small arms, but lost their resolve and fled when they mistakenly thought they heard the approach of cavalry. Later a number of men were arrested and sentenced to gaol or discharged from their bonds. ${ }^{3}$ Nearby in the poorly-policed parish of Bedlington on Friday, August I6, several men reputed to be Chartists fired a gun at John Carr, the colliery agent, and several of his assistants. Help was sent from among the reliable workmen of the Bedlington Iron Works, but the assailants were not captured. ${ }^{4}$ Elsewhere, the policy of quick arrest and conviction also ended stoppages at Gosforth and Walbottle collieries.

Walbottle had been largely influenced by its proximity to militant Winlaton and the iron-making villages on the south side of the Tyne. The men of Winlaton struck work on Monday and for the remaining week caused great uproar in the village with nightly parades and the firing of some guns kept there for ceremonial occasions. They also alarmed the district by processions in a large body through the neighboring villages, accompanied by their band and banners, in an attempt to bring out other ironworkers in their support. By the end of the week, however, after receiving no encouragement, they abandoned the strike and resumed work. ${ }^{5}$

${ }^{1}$ Ibid.; Buddle to Londonderry, Buddle, item I 4; Campbell to Lt. Col. Charles O'Donnell, H. O. $40 / 53$, ff. 659-62.

2 Thomas Burt, Autobiography, London 1924, pp. 24-25.

${ }^{3}$ Newcastle Courant, August 16, 23, 1839; Port of Tyne Pilot, August 24, 1839.

4 Newcastle Journal, August 17, 24, 1839; Newcastle Courant, August 23, 1839 .

5 Newcastle Journal, August 17, 1839; North Durham magistrates to Russell, August 13, I 839, H. O. $4 \% / 46$. 
A sense of security returned to the region rapidly. As early as Tuesday, August I 3, Colonel Campbell reported to London that "The neck of the business appears to me to have got a wrench and everything appears to promise improvement."1 Apprehension continued somewhat longer in the minds of others who were fearful of the consequences of Chartist meetings following August I2. The magistrates of Darlington dispersed a gathering on August is as soon as it began, ${ }^{2}$ while in Sunderland and Newcastle careful watch was kept on meetings which were addressed by Williams and John Taylor. ${ }^{3}$ However, by the last week of August decided optimism reappeared in statements, both public and private, which acknowledged continued bad feeling but looked for its gradual abatement. The astute John Buddle probably expressed the view of many when he wrote, "The thing is now ... completely at an end and we may expect an interval until some fresh bare is started. It is not likely that this will be too long, as we have some restless spirits stirring constantly amongst us."4

At no time in the summer of 1839 did the Chartists present a genuinely revolutionary threat. In spite of their brave words at meetings and their resolutions to meet "illegal force of government" with "constitutional resistance", their power was never great enough to be more than an alarming irritant. Crowded and angry meetings could be assembled to listen to emotional speeches, but most Chartist sympathizers were incapable of sustained action in the face of opposition. Without question some of the more extreme Chartists were prepared to resort to violence and Harney was probably right when he said that the men of Winlaton and Blaydon lingered on their way home from the "Battle of the Forth" on July 30, "hoping to see or hear some signal of renewed conflict in Newcastle and to which they unquestionably would have hastened back on the slightest encouragement." 5 The attempt at the "Sacred Month", however, showed the complete lack of organization and support in the movement for revolutionary action, in spite of the elaborate formation of branch associations that had been carried out in the preceding year. Local police authorities could deal with spontaneous outbursts such as those

${ }^{1}$ Campbell to Phillipps, August 13, I839, H. O. 40/46.

2 Durham Advertiser, August 23, 1839.

${ }^{3}$ Fife to Russell, August 24, 1839, H. O. 40/46; Sunderland magistrates to Russell, August I6, 1839, H. O. 40/42.

${ }^{4}$ Buddle to William Russell, Buddle, item 32.

s Newcastle Weekly Chronicle, July 26, I890. 
which occurred in Newcastle; even on August 12 they were not called upon to deal with anything beyond their capacity.

Two fundamental factors guaranteed that the strike would be limited and that, where it was attempted, it would fail. First of all, most of the workmen of the Northeast were too comfortable to want to strike. The confusion in the National Convention over the "Sacred Month", the division in policy between Newcastle and Sunderland, the lack of any real organization of the stoppage all contributed to the magnitude of its failure, but more important still, most workmen were not sufficiently hard put to take the extreme step of quitting their jobs. Visiting Chartist speakers were compelled, as Feargus O'Connor had been at Sunderland, to acknowledge how prosperous local working men seemed to be and had to argue somewhat abstractly that their audiences could not be content without the Charter. ${ }^{1}$ When the magistrates and military forces went out to stop the meeting of pitmen at Whitridge on August I 2, the men with whom they conversed told them, "it was for their political rights they were struggling and quite unconnected with the question of wages, respecting which they had no complaint to make."2 General Napier, whose sympathy for the plight of the workers is well known and who had recently talked to men working in a pit, wrote of the colliers near North Shields in December 1839 that he trusted "to their own good sense and good wages ... They are too well off to make good rebels." 3 Few workmen in the district were prepared to strike for principle alone.

The other important factor in the Northeast was the expeditious action taken by the magistrates to preserve order. Already before the strike occurred, the two street incidents in Newcastle and the arrests both there and in Sunderland had discouraged all but the most determined. They also warned the magistrates to take firm preventative measures. The prohibition of meetings, the strengthening of civil and military forces, and the publicity given to these steps not only warned off Chartists, but probably gave security to those who feared intimidation. When the strike occurred, display of police force and speedy arrest and conviction for breach of bond of key leaders who did not return after the first day quickly broke the strike in the colliery districts. ${ }^{4}$ The authorities struck at the town leadership as well by arresting John Bell, the printer of the Northern Liberator, whose

\footnotetext{
1 Sunderland Herald, June 28, 1839.

2 Campbell to O'Donnell, H. O. $40 / 53$, f. 660.

${ }^{3}$ Napier to Phillipps, H. O. 40/53, ff. 853-54.

4 Newcastle Journal, August 31, 1839 . Arrests and convictions took place at Seghill, Cramlington, Gosforth, Walbottle, and Thornley. A number of men published abject apologies for their actions later in the month in hope of reinstatement (ibid.).
} 
name appeared on the handbill calling the strike in Newcastle, and Miles Brown, William Byrne, and James Bald Owen in Stockton, and Nicholas Bragg and James Batchellor in Darlington, all major figures in the movement. The magistrates responsible for Thornley and Winlaton showed less energy than their colleagues north of the Tyne and drew sharp criticism on themselves for their lax behavior, but without the support of a general stoppage, workmen there could not long remain out. ${ }^{1}$

After the summer of 1839 Chartism did not again lead to violence or overtly unlawful action in this area. There may have been a conspiracy for a general rising that included Newcastle at the time of the John Frost rising in Wales, but this has never been demonstrated conclusively. ${ }^{2}$ In $\mathrm{i} 84^{2}$, although economic conditions were far worse and privation acute, Chartist activity did not go beyond collection of signatures for the petition and public meetings carefully watched by the police. ${ }^{3}$ The 1848 movement, which aroused such great anxiety elsewhere, hardly caused a stir in Newcastle. Chartist meetings and organizations continued on for many years in the region and dedication to the Chartist principles remained strong, but by this time it had become a moderate movement with increasingly numerous relations to middle-class reform and it had lost that emotional, and potentially physical, force evidenced by the sanguinary oratory of 1 838-39.

\footnotetext{
${ }^{1}$ Buddle to Londonderry, Buddle, item I 8; Buddle to Edward W. Donnell, ibid., item 20; Newcastle Journal, August 17, 24, 1839 .

2 Thomas Ainge Devyr in his Odd Book of the Nineteenth Century, Greenpoint (New York) 1882 , claims that all was in readiness for cooperation with other parts of the country during the winter 1839-40 (pp. 195-209). A report from an operative in Balliol College Library, Oxford, Urquhart Bequest MSS., I. E. I., ff. 78-80, supports this. The Duke of Northumberland was sufficiently alarmed at the revival of Chartist activity at the time to have a sloop and marines stationed in the Tyne, as he had done earlier in 1832 (Duke of Northumberland to Russell, December 14, r839, H. O. 40/46).

${ }^{3}$ Series of notes from John Stephens to J. H. Hodgson, August 23, 1842, Newcastle upon Tyne City Archives, Hodgson Deposit, Letter 86.
} 